Please do not remove this page

RMIT

UNIVERSITY

\title{
Managerial technologies and power relations: a study of the Australian waterfront
}

Gekara, Victor; Fairbrother, Peter

https://researchrepository.rmit.edu.au/esploro/outputs/9921858791301341/filesAndLinks?institution=61RMIT_INST\&index=null

Gekara, V., \& Fairbrother, P. (2013). Managerial technologies and power relations: a study of the Australian waterfront. New Technology, Work and Employment, 28(1), 51-65.

https://doi.org/10.1111/ntwe.12003

Document Version: Accepted Manuscript

Published Version: https://doi.org/10.1111/ntwe.12003

Repository homepage: https://researchrepository.rmit.edu.au

(C) 2013 Blackwell Publishing Ltd

Downloaded On 2023/04/27 00:54:39 +1000

Please do not remove this page 
Thank you for downloading this document from the RMIT Research Repository.

The RMIT Research Repository is an open access database showcasing the research outputs of RMIT University researchers.

RMIT Research Repository: http://researchbank.rmit.edu.au/

\section{Citation:}

Gekara, V and Fairbrother, P 2013, 'Managerial technologies and power relations: a study of the Australian waterfront', New Technology, Work and Employment, vol. 28, no. 1, pp. 51-65.

See this record in the RMIT Research Repository at:

http://researchbank.rmit.edu.au/view/rmit:20312

Version: Accepted Manuscript

Copyright Statement: (c) 2013 Blackwell Publishing Ltd

Link to Published Version:

http://dx.doi.org/10.1111/ntwe.12003 


\title{
Managerial Technologies and Power Relations: A Study of the Australian Waterfront
}

by

\author{
Victor Oyaro Gekara and Peter Fairbrother \\ Centre for Sustainable Organisations and Work \\ Business College, RMIT University
}

Australia

Submitted to the New Technologies, Work and Employment Journal, 2013

\section{Biographical Notes:}

Dr. Victor Oyaro Gekara is a senior lecturer of International Logistics and International Trade in the School of Business IT and Logistics at RMIT University, Melbourne Australia. He is a member and research cluster leader of the Centre for Sustainable Organisations and Work. His research interests include the political economy of work and employment in the context of globalisation.

Contact Details: School of Business IT and Logistics, RMIT University, Building 80, Level 9, 445

Swantson Street, Melbourne. VIC 3000. Tel: +61 (03) 9925 5550. Email: victor.gekara@rmit.edu.au

Professor Peter Fairbrother is a professor of International Employment Relations and Director of the Centre for Sustainable Organisations. His research interests include studies of trade unionism, work and employment restructuring and regional development and revitalisation in the context of globalisation.

Contact Details: Centre for Sustainable Organisations and Work, RMIT University, Building 80, Level 9, 445 Swantson Street, Melbourne. VIC 3000. Tel: +61 (03) 9925 51505. Email:

\section{peter.fairbrother@rmit.edu.au}

\section{Abstract}

In recent times, the modern port has been characterised by rapid changes in work technologies and the consolidation of logistics functions. These changes signify an important re-composition of the port labour process and raise questions about the strategic location of frontline manual jobs. This research examines how these changes have played out in the Australian ports industry, developing the argument that a depersonalised managerial form of control is emerging with potentially challenging consequences for worker solidarity and collective organisation. The argument is that relations between port management and workers has changed significantly, with a reconfiguration of job roles, skill compositions and thus workplace power relations. It is informed by qualitative research at two Australian ports, exploring the organisation of work and the impact of recent technologies.

Key words: Labour process; managerial technologies; port operations; work organisation; strategic jobs; power 
Word Count: 8,606 words

\section{Introduction}

Ports are key hubs of international transport and logistics; no longer merely facilitating the sea-land transfer of cargoes. Although they have always constituted a key part of the international economy, it is only in recent years that global terminal operators have begun to dominate the industry, replacing national state controlled port authorities (Baird, 2000; Slack and Frémont, 2005). Alongside this ownership shift, there has been an increasing uptake of sophisticated advanced technologies, particularly at container terminals, introduced to organise both the flow of goods and their physical handling (Kia et al., 2000). With the involvement of privately owned international operators such as Dubai Ports World, Hutchison's and Port of Singapore Authority (PSA) International, port facilities effectively are now integrated as key and central nodes in the global logistics and supply chains (e.g., Haezendonck et al., 2000; Mangan et al., 2008). Port terminals have become central business catalysts, around which production and logistics facilities are established (Bichou and Gray, 2005).

In this transformation, the nature of work and employment has changed and become more complex and diverse. As noted by Bichou and Gray (2005):

Ports are complex multipart organisations where institutions and functions often intersect at various levels, which makes it difficult to identify who does what, and why in ports (p.83).

But, underlying this observation is the suggestion that there is an opaqueness to these organisations and within ports as sites of work and employment..

Such features suggest a set of themes about the relationships between technological change and work control and conflict. One possibility is that in such circumstances employers seek to improve and change work practices via technological innovation to secure their control over the work process and achieve productivity and other gains. Another consideration is that with restructuring of work processes, workers both informally or via their unions seek to relay the foundations for exploiting and utilising the resources that come with technological change (e.g. Finlay, 1988). The question is; how have such changes affected the port labour process and what are the implications for power relations between management and waterfront workers?

Our principal proposition is that the re-composition of power relations within the port terminal workforce is based on a contradiction. On the one hand, the shift in ownership and the associated managerial changes comes with a renewed emphasis on restructuring work processes via technological and organisational innovation. The outcome is depersonalised process of organising work, apparently no longer organised by people but by the technological process itself. On the other hand, the reskilling of the workforce associated with the introduction and use of advanced technologies repositions workers in relation to their potential exercise of power. These workers, while building on past skills and work tasks, are now part of an extended work process that goes well beyond the port terminal itself. The appearance 
of technological determinism obscures the very leverage that working with this technology provides. Nonetheless, the opaqueness of these relations raises difficult organisational and capacity building questions for trade unions.

\section{Debates}

Two sets of debates inform this analysis. First the changes that have taken place in relation to port work point to the ways in which work is being reorganised in line with the introduction of advanced technologies. Second, these changes raise questions about the ways in which such technological change is associated with changing power relations. To help understand these changes, a distinct analytical framework is presented.

\section{Advanced Technologies}

In recent decades, transport companies have increasingly invested in advanced technologies that enable them to reorganise the workplace and workforce with the aim of securing greater efficiency and productivity. At port terminals, the goal is to achieve rapid and cost effective transfer of goods in and out of the port. Additionally, across the logistics sector as a whole, there has been a rebalancing of job content with a shift in emphasis from the physical handling of goods to the organisation of work via automation and electronic information systems (Butcher, 2007). New information and communication technologies, such as electronic vessel loading plans and manifests, and automatic identification and data capture (AIDC), for asset tracking and security, have revolutionised the ways in which most port work is carried out.

The impact of technological change in the ports sector, particularly in its most recent form, via computerisation and the digitalisation of work procedures, is yet to be fully understood. What is evident, however, is that transformations, in the 1950s and through to the 1970s, had a rather deterministic impact on port work leading to a major reduction in staffing levels, with the shift from manual to more mechanised work processes associated with containerisation and automation (see Barton and Turnbull, 2002; Finlay, 1988). This makeover was largely shaped and fashioned by changes taking place in shipping, with port operators adopting technologies and procedures to meet the demands of containerisation and inter-modal transportation (Notteboom and Rodrigue, 2008; Slack, 1993). With the subsequent introduction of managerial computerised systems, more complex patterns of change have taken place (see Walsham, 1993 and in relation to shipping, Morris and Donn, 1997). In relation to port operations, the term 'port work' lacks its past clarity (Bichou and Gray, 2005). In some instances, those who hold jobs critical to the workings of the port are in fact located off-site or even offshore (Hall, 2009). The question is; what impact do such developments have on the port labour process?

The recent transformation of the port labour process has consequences for port workers although the impact in terms of the organisation and operation of the labour process has not yet been addressed (see Bonacich and Wilson, 2008; Davis, 2007; Hall, 2009; Turnbull, 2001; Turnbull and Wass, 2007). One impact may be in relation to strategic jobs, that is, the strategic positioning of frontline jobs in the ongoing balancing of power relations at the waterfront. 


\section{Questions Relating to Power}

The literature on integrated work practices and processes tend to emphasise one of two possibilities: worker empowerment and the enhancement of skills (Womack et al. 1990) or the reduction in job autonomy (Turnbull, 1988). Bayo-Moriones and others (2010: 64 - 69) identify four key job characteristics: job variety, job autonomy, job interdependence and job complexity. For these authors, the main concern is with the implications for competitiveness and human resource management policy and practice. Our concerns are different, namely that changes in job tasks may lead to a redesignation of job roles within a complex of work and employment relations that can impact on the exercise of collective power within the workplace.

There is much debate about the concept of power (e.g., Lukes, 2005). Nonetheless, there is strong agreement over the fact that power encompasses a variety of logics and arrangements. As argued by Held (1995):

...power expresses at one and the same time the intentions and purposes of agencies and institutions and the relative balance of resources they can deploy with respect to each other. ( $p$.

170)

The question of power is critical to an assessment of the recomposition of work and employment relations.

Job composition and re-composition (for example following technological innovation) may enable jobholders to impact authority relations either through a mass presence or because of leverage that derives from exercising specific tasks (for example by handling information systems). In this respect, it can be argued that such job clustering contributes to the unmaking and remaking of class relations (Silver, 2003). As job clusters acquire a salience in the labour process, then they may occasion a reassessment of the ways in which class relations are constituted. Of course, such changes draw attention to power and the exercise of it in the context of work and employment. In this respect, Wright (2000: 962), for example, presents a useful distinction between 'structural power' (the 'strategic location of a particular group of workers within a key industrial sector') and 'associational power' (the collective organisation of workers, in trade unions and the like). These two logics inform the analysis, as developed below.

\section{Technologies and Power}

With the recomposition of work relations, occasioned, for example, by the introduction of advanced technologies, managerial capacities may change. The exercise of managerial authority may be relocated with the embrace of technological innovation (Dodgson, 2000 and Tidd et al., 2005). Of more relevance, Edwards in an early seminal work, argues that management-worker relations are structurally defined, with the implication that workplace conflict can be explained by what he terms 'structured antagonisms inherent in private capitalism' (Edwards, 1986: see also Burawoy, 1979). The implication is that with the restructuring of worker-management relations, those with leverage over the work processes may find themselves in contradictory class positions (see Carchedi, 1977). 
Workers may be able to begin exercising their bargaining capacities based on 'strategic location within the process of production' (Silver, 2003: 13). Where jobholders occupy positions that enable them, either individually or collectively, to influence management and supervisory staff, then they are strategically located. Such potential has implications for collective organisation, that is, the way a trade union organises and exerts its capacities and activity (von Holdt and Webster, 2008). With specific reference to port work, the question is whether, and how, the new technologies may have occasioned the re-definition of strategic jobs and consequently, the potential influence of workers' unions at the waterfront.

\section{Approach and Method}

To explore these themes, two inter-connected questions guide the study. First, in what way has port work been restructured via the introduction of advanced technologies, with implications for managerial practice and work tasks undertaken. Second, has the introduction of advanced technologies into port work led to a potential rebalancing of power relations between management and workforces?

To answer these questions, we conducted a qualitative study of port work in Australia's largest container ports, Port Melbourne and Port Botany, Sydney. Data were collected in 2010 and 2011 by way of semistructured interviews with port terminal managers, frontline workers and union representatives in these ports. The focus was on the operations of one terminal operator (these two terminals account for over three quarters of the operator's total container movement and around 40 per cent of all container movement in Australia). Interviews were conducted with terminal managers (5), work supervisors (4), front-yard team leaders (2), workers, and union representatives (4). Due to access difficulties the data for one of the operators is more comprehensive. In addition, over 45 interviews have been conducted between 2004 and 2011 with union representatives from the main transport unions, Maritime Union of Australia, Transport Workers' Union and Rail, Tram and Bus Union, at all representative levels, delegate, branch officers, national officials and international officers and officials. This long-term data contextualises the analysis presented in the paper.

Altogether, fifteen targeted interviews were conducted, with several follow-up e-mail and telephone correspondence. Each interview lasted about 90 minutes. The main focus of the interviews with management was on the type of technologies that the companies had introduced into their operations, the reasons for their implementation and their effect on operations, work and employment. With front yard workers, we explored their experiences of the new technologies and how their use had changed the content of their jobs. With union officials, including stewards at the terminals (and the more long-term data), we generated accounts of changes taking place in the workforce and the implications for union organising and influence. The digitally captured interviews were transcribed, coded in NVivo and thematically analysed.

\section{The Context: Ownership in Australian Container Ports}

Globalisation is associated with the flows and transactions of an interwoven capitalist economy (Fairbrother et al., 2009; Tarrow, 2005). Three interconnected phenomena define these developments: an increase in international trade and competition across economic regions, the expansion of managerial 
coordination and control across national borders within trans-national corporations (TNCs), and the 'globalisation' of capital markets in terms of ownership and the volume, and speed, of international financial transactions (Whitley, 1999: 119). These developments form part of the refocus of the role of transport and communications in addressing what Hudson terms the 'tyranny of distance' (2001: 255).

These developments have played out in the broader maritime sector in a significant way. The last two decades have seen an increasing concentration in the ownership and integration in shipping lines, container terminal operators and (land-based) transport and logistics companies (Suykens and Van de Voorde, 1998). These processes have led to the internationalisation of port organisation, management and employment practices (Hill, 2005; Turnbull and Wass, 2007). Employer strategies are a critical element in determining the extension of global business and the adoption of new technologies of work. The effectiveness of such strategies, however, is often shaped by the nature of ownership and control in the industry. In the Australian ports industry, Port Authorities (government owned corporations) bear the responsibility for developing and maintaining the primary infrastructure to handle shipping and cargo traffic, while stevedoring companies mainly focus their attention on the superstructure needed for actual cargo transfer.

Many governments around the world have ceded control of ports to private operators. Initially, in the 1980s, shipping companies began taking a control interest in port terminals with some developing and/or acquiring dedicated container terminals in strategic locations. Cost pressures and the need for greater visibility and control of global logistics chains mainly informed this move (Suykens and Van de Voorde, 1998). By taking over port work, they aimed to more effectively synchronize port work with shipping timetables. To illustrate, by 2000 , the number of dedicated container terminals totalled 69 with the major carriers - Maersk Sea Land, Evergreen, MOL and K-Line dominating the trend, with 46 terminals in strategic locations in Asia, Europe and North America (Haralambides et al, 2002:23).

More recently, in the 1990s, highly specialised, capital-rich private stevedoring companies known as Global Terminal Operators (GTO) have come to the fore (Slack and Frèmont, 2005). These companies introduced new and sophisticated data-based technologies into port work, which advanced and further consolidated the restructuring of the port labour process that commenced with containerisation (Vigarié, 1999; Beresford et al, 2004). The immediate focus for the GTOs was to significantly reconfigure work and skills deployment via soft managerial technologies so as to achieve greater efficiencies, productivity and upstream-downstream logistics integration, as well as achieve greater control over the frontline workforce (see Finlay, 1988).

Most of these developments are evident in Australian ports. While most of these ports remain state owned, they have been corporatized and operate as commercial entities (Tull and Revely, 2001). In the 1980s and 90s, many port authorities built new facilities to handle container traffic. In 1995, a new legislative framework for port management in Melbourne transferred the control of labour to stevedoring companies (Griffin and Svensen 1998), including some GTOs. These private operators focused on a labour process rationalisation, with an initial focus on cost and productivity at the terminals. The longerterm intention was to use new workplace technologies to further reduce manual handling, improve 
control over cargo shipment and gain greater logistics network visibility. This objective is explained by two terminal managers:

Of course, the cost of our operations are the main driver... we are in business to make money and the high cost of labour in this country don't help much. The technologies help to ... reduce staffing levels but also increase efficiency (Terminal Operations Manager, 2010)

Another manager explained:

The technology is important for the coordination of all out clients... it means that we are all reading from the same page so that we save time and reduce costly errors (Terminal Logistics Manager, 2010)

These processes, however, have not happened without industrial friction between management and the powerful port workers' union - the Maritime Union of Australia (MUA), well illustrated by the 1998 waterfront dispute (see McConville, 2000 and Dabscheck, 2000; Griffin and Svensen 1998).

\section{Advanced Technologies and Port Work}

The dominant form of paid work in the early twentieth century - industrial, standardised, often large scale and largely male - has been transformed by, among other things, technological innovation. Although the labour process is structured differently across terminals, the basic workflow is simple. To illustrate, for import cargo, containers are offloaded using ship-to-shore cranes operated by a crane driver/operator. The container is then picked from under the crane by a straddle, operated by a straddle driver, and moved to the appropriate stack within the yard from where it is later picked and moved by truck or rail to final destination. The workforce is organised in teams (also referred to as gangs). At the terminals studied, a typical team is organised around one crane and three straddles. The team comprises seven members; a team leader, two crane operators and four straddle drivers. The equipment operators normally work rotationally.

From the 1990s onwards, advanced information management technologies have been introduced, often accompanied by the introduction of more automated work practices (Kia et al., 2000). These technologies are mainly used to increase operational efficiencies and eliminate costly delays for ships and cargo owners. Kia and colleagues (2000), observe that 'a properly designed, computerised container control system increases the operating efficiency of the terminal' (p. 333). At both Australian terminals, information is transmitted and processed before out-bound containers arrive at the port. Likewise, associated information is transmitted in advance to the terminal and processed long before a vessel arrives. This information in the form of shipping manifests and stowage plans, received in advance of the cargo, enables terminal operators to plan loading and discharging activities, and (re)arrange the container yard for easy stacking and retrieval. Information technologies are used to transmit and process data between the various operations units involved in the processing of containers, including back-office monitoring teams, front-yard mobile equipment teams, the ship, and in some cases, involving remotely-based planning teams. All involved in the export/import container movement are increasingly linked via information technologies. Typically, three systems of 'work' run concurrently: 
1. an online multi-point system, which connects users and all container export/import parties, remote planners, yard monitors and inland yards;

2. an offline central system, which connects the monitoring back-office with the front-yard mobile crews and records the movement of containers into/out of and around the yard; and

3. a limited online multi-point for direct communication between monitors, crane operators, straddle drivers and ground team leaders (Kia et al., 2000).

These technologies have enabled the systematic re-rationalization of the port work process.

One outcome of these practices is a further redefinition of the port and port work in terms of location, roles and demographics of the workforce. Many functions formerly performed at the waterfront have been consolidated in back-office computer laboratories or shifted to locations outside the traditional port premise. Another outcome has been a restructuring of the port workforce skill-sets and a blurring of the white collar/blue collar distinction, with consequences for strategic power relations at the waterfront.

\section{The Port Labour Process}

The ports of Melbourne and Sydney are the largest container ports in Australia. They are responsible for the movement of about 80 per cent of the total container trade in the country. Two terminal operators are responsible for this movement, Patrick Stevedores and Dubai Ports World (DP-World). These two operators have introduced similar Information Communication Technologies (ICT) into their port operations, such as Information Management Systems (IMS). At the two terminals, the IMS arrangements are loosely referred to as Community System (CS), Internal Mainframe System (IMS) and Equipment Control System (ECS), powered by Navis SPARCS N4 respectively. This operating system was developed by Navis and enables operators more system functionality and operations visibility within and outside the terminal. It is used for yard planning and management, vessel stowage planning, and crane and straddle scheduling. At the terminals, for example, the ECS is simply referred to as SPARCS. These IMS components interface with each other to create a continuous workflow for export/import containers. As they become core to the texture of port work, the operations tasks that they encompass are increasingly becoming more and more central to the flow of work.

The increasing adoption of these systems means that currently about 70 per cent of the containers handled at each port terminal fall under the category of 'paperless' trade. A logistics manager at one of the terminals explained:

We have external, online, facilities for customers to use. One of those is the one-stop shop company, which is a separate entity, although this company has interests in it, along with our opposition across the road... So that website, if you like, allows people to 'PRA' (they enter the data for a specific container) their export containers. They sort of create the container's identity in the online system for purposes of receival to the terminal. [...] a third party in the community will enter the data and detail on this one-stop website system and then that becomes a record, which is visible to us. In the case of an export container, the system will 
show us all the details but showing its location as 'community', meaning not inside the terminal and expected to be received within the receival window. That website interface is of course within our mainframe system (Terminal Logistics Manager, 2010)

The system has been called the 'one-stop system' to show that the customer, in this case the shipper, only needs to enter cargo details on the system once, which is then available to all concerned parties. Unlike previous arrangements, they can also access all the services in an integrated way rather than separately. It also means that through this system the cargo owner has access to all services required for the processing of an import/export container.

The technology significantly simplifies the process for the port users while allowing the terminal operators greater logistics visibility, efficiency and security. As explained:

People in the community - shippers, exporters, trucking companies, freight forwarders, customs brokers - want more control, and with the entering of export data for a container, external to the terminal has given them a lot more control, where they've got much more flexibility [e.g.] last minute packing of boxes, editing details and so on. They just go straight to a website and enter a container and update details (Terminal Logistics Manager, 2010).

The process is punctuated by a series of transfer points, the first of which is when the shipper creates the container manifest, that is, the container identity, including container number, cargo type, departure terminal, pick-up and delivery dates, destination and name of carrier. From here all parties directly involved in the container's movement, including the trucking company, customs department and the terminal operator, have access to these details. The trucking company, for examples, can arrange pickup and book a delivery slot at the terminal. Upon pick-up, the driver (usually with a hand-held computer) updates the container's status, indicating that the container has entered the system but is yet to be delivered to the terminal. By the time the truck arrives at the terminal gates, the container details are already in the terminal mainframe system. At the gate, the container number is scanned using Optical Character Recognition (OCR) technology. This interface provides the link between the 'community' and the internal mainframe system whereby the container is identified in the terminal's database. Once the container is digitally recognised the next phase is activated, that is the offline system (so known because it is only used within the terminal to coordinate container movement and processing), initiating the provision of a yard location and associated movement around the yard. This process is described thus:

As the truck drives through [the gate] ... we use Optical Character Recognition (OCR) technology, which is basically a camera reading a registration number, reading a container number and searching for that information in our database. The transaction of reading that information and confirming it creates the manifest within our internal mainframe system [so that] our equipment control systems and others, are then aware that container is in the terminal. Then it interfaces with equipment control and ultimately to the straddle (Terminal Logistics Manager, 2010). 
Seemingly, two processes are in operation at the terminal gate - container recognition and security clearance for the truck driver. These processes are facilitated by the multi-faceted manifest earlier created by both the shipper and the trucking company. It is only after positive identification and verification of the container, truck and driver that a series of boom-gates are automatically opened to allow the truck through. The system also schedules the truck and allocates a stacking slot. When this is done the status of the container changes from 'community' to 'truck queue', indicating that the container is in the terminal waiting unloading at a designated area. An electronic board, linked to the internal offline system informs the driver where to go and drop the container. From this point on the details of the container are also available to the monitors (also known as controllers) who use it to manage operations in the yard. They are, for example, able to send real-time details to straddle operators about containers, their locations in the yard and instructions about their movement.

The next transfer point is when a straddle picks the container from the truck and places it in the designated stack. This operation is within the limited online equipment control system. This system facilitates communication between the monitors and the mobile equipment crew, particularly the straddles teams. A set of twist-locks located on the straddles (securing the containers for lifting and dropping) is electronically enabled to send signals to the system with updates about pick-ups and dropoffs within the yard. Thus, when the straddle drops the container, the unlocking mechanism on the twistlocks automatically sends signals, which update the status of the container. From then on, until the container is moved, the system will show the specific location of the container in the yard.

At this point, the responsibility of the trucking company is discharged. The final leg takes place when a straddle picks it up and drops it under the ship's crane for loading onto the ship. Once again, the unlocking of the straddle twist-locks sends electronic signals, which update the information on the system. At this point, the container is considered loaded and the status changes accordingly. Clearly, these technologies enable automatic accurate step-by-step record keeping; a previously tedious, labour intensive process prone to costly tally errors. In terminals where the technology is more advanced, such as Singapore and Rotterdam, the cranes are also equipped with technology similar to the straddles (Kia et al., 2000). However, the terminals in Melbourne and Sydney are yet to introduce similar capabilities.

Advanced information management technologies have similarly enabled a seamless international transfer of information and loading plans for ships. When a ship departs from a previous port, the terminal receives a cargo manifest, as well as the loading plan from the carrier's remote planners, who may be located anywhere in the world. In the case of Patrick, the loading plans are transmitted to its team of planners at the National Operations Centre (NOC) for processing before being fed into the terminal's mainframe database. The information shows the yard team the import containers to offload and in what order the export containers should be loaded and stowed. The process is described thus:

A ship's file is 'dumped' into our mainframe computer in terms of the imports by the carrier's planners ... done electronically. Then we have both the discharge and the backload. So a planner somewhere in Australia, anywhere - in the world if you like - can plan the vessel... ' want these containers to be discharged from this bay, from this deck, and then I want these 
containers discharged from below.' Then in this order, 'I want these containers, which are in the yard, loaded down below until that hatch is finished'. So we call that planning/sequencing ... We use this system to do that, combined with that other system [SPARCS]; always talking to each other (Terminal Operations Manager, 2011).

Thus, information technology has become the main tool used by these GTOs for shaping and focusing the port terminal labour process.

\section{Assessment}

With the introduction of these managerial technologies port work has significantly changed with a reconfiguration of job roles and skill composition, with implications for workplace power relations. In the process of these changes, some roles have gone while others have been shifted off-site. The manual monitoring and recording of cargo movement at various strategic points in the labour process has ended and been replaced by data management systems (see also Kia et al, 2000). Some of the jobs that remain in place have experienced contraction, routinisation and work intensification. As explained by a crane driver:

It is really quite simple but it can get very repetitive and boring ... it's not easy doing this continuously for hours so we take regular breaks ... you'd run mad, mate... (Crane Operator, 2010).

Similar descriptions were given by straddle drivers, where, for example, a straddle operator saw his role as: 'you pick that box from here drop it there and pick that one and drop it somewhere else' (Straddle Operator, 2010). The outcome is a more technologically integrated labour process, but one where much of the work has become routinised while particular sets of jobs have been reconfigured with an emphasis on coordination. Such developments have implications for structural and associational power (Wright, 2000: 962).

\section{Opaque and Depersonalised Forms of Managerial Control}

Within the terminals, there has been some strategic consolidation of operations from the front yard to back-office computer management laboratories where yard monitors receive, analyse and provide realtime information and directions to the front-yard mobile equipment crews. These measures give management greater control of the container movement process, as explained by a terminal manager:

We've recently moved to centralised planning within our company to improve the control [of the work process]... plus, because a lot of the big customers have centralised planning now as well; they don't want to talk to five [different] ports in Australia (Terminal Operations Manager, 2010).

These changes are driven by companies seeking to establish an integrated labour process within the ports; a process which links road transport, port operations and shipping in a seemingly seamless chain. Managements have taken the opportunity provided by these technologies and work systems to break the relationship between job titles and managerial and supervisory responsibilities.. Some tasks have ended: 
People standing with clipboards and pencils. You don't have that anymore and that's replaced by some systems I've described here - SPARCS, ECS, our internal systems mainframe. They're all data processing type work. Still clerical but requiring a higher level of, I think, aptitude to manage efficiently. (Terminal Manager, 2010).

The outcome is an integrated form of managing work tasks and arrangements:

[The] monitor allocates where [others] go generally. So the straddle driver just basically follows the screen on his straddle. It tells him if he's discharging a box where to take it and if he's loading a box where to pick that box up from, bring it back to the hook and then we'll load it. It also gives him a sequence number that they must follow; load weights and various things like that on his screen...

Well the shift manager will give you your sheet of work for the day which will give you a bay on the ship or maybe numerous bays on the ship to work telling you what containers need to be taken off and what containers need to be put on, their locations on the ship. So I work out and make sure we're doing all the correct ones... That's pretty basically it and how it all works.(Team Leader, 2010)

This integrated form of managing the labour process creates a situation where the exercise of control becomes opaque. Previously, portside team-leaders, for example, were in charge of organising and supervising their 'gangs' in the process of loading and unloading and movement of cargo around the yard. They also played a key role in the planning and execution of cargo operations. Their role has been greatly diluted and is now integrated into a broader system of operational arrangements. Specific tasks have been moved to yard 'controllers' who (by way of digitally based communication technologies) have a complete 'bird's eye' view of yard operations and thus able to monitor and direct the work remotely. Furthermore, team leaders' involvement in cargo stowage and unloading plans has greatly diminished and shifted to off-site and/or centralised planning locations. For one company. the physically remote National Operations Centre coordinates cargo and vessel planning for all terminals, and an appointed one-stop-shop services firm manages all the terminals' information and data flows for this company.

A manager pinpointed the changes in the following way:

Any problems that arise during the course of the ship, like there might be a lost container or there might be a container that doesn't fit where it's planned to go and they have to go to the ship manager and he calls Melbourne now. It used to be here [Sydney] they would do it all in house here, but now there has got to be call to Melbourne and they replan that container or get a substitute container, whatever (Terminal Clerk, 2010).

Planning and manifest activity no longer takes place shipside. Further. In relation to the development of loading-plans, this manager also said: 
Melbourne do that now. It was done here [Sydney] up until a few months back, but it is all done in Melbourne now and the ship manager just prints off the information up here and gives it to the relevant team leaders and that's what happens (Terminal Clerk, 2010).

The result is that work tasks are seemingly controlled externally, by the data management system that is now in place, and in the process of further refinement.

The labour process thus increasingly takes on a material (shifting containers with cranes) and a non-material face (operating data management systems). Increasingly it appears that an integrated managerial system of operation sets the pace, monitors and secures outputs. No longer is the worker directed and supervised in a traditional sense by a supervisor or manager. Of course, there is people intervention at different points in the labour process, but this intervention is more opaque: neither as direct person supervision nor as self-management. The illusion is that it is not the 'human' manager creating the work experience but rather technological sophistication. Underpinning this appearance, is a new depersonalised managerial system with powers vested in an emerging category of portside workforce. Critical to this process are the monitors, who themselves exercise these powers (of coordination and supervision) via technological intermediation. In this depersonalised form of control, work appears to be organised and regulated via the system, rather than by the manager qua manager ( $c f^{\prime}$, Carchedi, 1977 on contradictory class locations).

\section{The Reconfiguration of Worker Power}

These developments have also had another significant type of impact at the waterfront. The systematic rationalisation of work and employment through new technologies has relocated dockworker levers of power. In the past dockworkers were able to exercise power as a collective mass, forms of associational power. They were well organised, often militant, and crucial to the process of moving goods in and out of the port. They used their associational power to (1) improve their own pay and conditions (Turnbull and Wass, 2007) and (2) improve the pay and conditions of other workers (for example, seafarers on Flags of Convenience vessels (Lillie, 2004); and (3) support other transport workers (Barton and Fairbrother, 2009). Therefore, for (dock) workers, occupying and organising the mass of manual work was the key to "decent work" on the waterfront.

This form of organisation around manual labour, however, has given way to a smaller and more diversely skilled workforce. In this regard, there has been a general diminution of mass control and, by extension the exercise of power through such collective action. The computerisation and relocation of job roles from the front yard, which constituted the traditional centre of dockside solidarity, has seemingly blurred the line between the manual workforce and the non-manual one (see Carchedi, 1977).

Such developments create dilemmas for unions, The depersonalisation of control and promotion of the illusion of technological determinism has led many 'old' and 'new' port workers to adopt the 'nothing we can do about it' view towards increasing managerial control. Of note, and a further 
complication is that no longer are all holders of non-managerial jobs sourced from within, that is from the existing pool of unionised casual workers. Instead, management seeks to recruit those working with the advanced technologies from outside the port, breaking the traditional recruitment procedures in ports and, by extension, continuity in union membership. Nonetheless, the maritime union has been successful in retaining career progression within the port workforce, particularly to monitors and like personnel. At the same time, it has maintained the movement into permanent posts in yard work by causal workers.

There is a view that the new 'class' of workers, the monitors and related occupations involved in coordination and recording activity, lack a strong commitment to union values. As stated:

...once they have moved from here to those offices, they change mate... they are no longer one of us (Straddle Driver 2010).

While this comment was made in general reference to managers who had risen up the ranks and were now seen to be on the other the other side, it also referred to these dockworkers who operate from the control rooms. Management has therefore succeeded in creating a set of 'greyside' workers, in particular with the monitors, who are neither managerial nor workers in a traditional sense.

A second step is to focus on the recruitment the casual workforce into the union as a reserve pool of permanent members. But these workers are not necessarily seen as active union members. One steward (and others) described the casual workers as 'not very committed... not like the permanent people' (Terminal Union Steward, 2010). Nevertheless, there are unclear consequences flowing from this complex of promotion arrangements. The permanent workers who are promoted, to monitors and the like, for example, are not seen as reliable union members by some. There would appear to be a growing problem in relation to the stimulation of a union consciousness among members.

A key impact of these new managerial systems, and one which is indicative of changing union capacities, relates to diminishing workforce size at the waterfront. Some of the technology induced changes were described as follows:

... so obviously it's been a major change that l've seen plus mechanisation of the containers, all that sort of thing....That's reduced the workforce considerably. They want more out of the labour. They want them to do more work, but of course the machinery is a different class now to what it used to be, more modern and more efficient (Port Terminal Staff, 2010).

A union official organising within the terminal presented the situation thus:

So yes I suppose there's been more technology in it which is done over some clerical jobs. That's probably impacting now with some redundancies which would come through earlier this year. Now they're coming back with some more redundancies because of the paperless trading and things (Port Union Official, 2009). 
This official, who has worked at the terminal for more than fifteen years and who went from 'wharfie' to the senior supervisory level, recounted how the number of members in crane teams (gangs) had drastically declined with the introduction of new technologies starting from 2000 . As stated: 'a container gang used to have five drivers for one gang plus we were required, plus we had two foremen' (Union Official, 2009). Currently, a typical gang has only two crane drivers and a team leader.

Such developments create problems for the unions. There is a recognition that the levers of workers' power in the past have been negated. As stated:

The lads do not want to strike all the time... we are not gonna down our tools every time there is an issue. That is not appropriate anymore (Terminal Yard Monitor, 2010)

This comment (one of many) also reveals the ways in which the portside work is increasingly part of an integrated information and communication system that creates a different sense of 'tools' of the trade. The difficulty for unions organising at the waterfront in the unfolding situation is that not only has the centre for dockside solidarity been systematically undermined and dispersed, technological determinism seems to lead to a view that this type of change is inevitable.

Management expressed the view that while the unions in the ports were deemed as 'strong' they ever were they also thought they had an effective balance in place.

Interviewee: I've seen managers come in here and try to change the waterfront from different spheres of where they've been working. They could be in another line of work and they come in here and we'll do it this way, we'll do it this way and it doesn't work. Then you've got to contend with the union too. You've got to remember that.

Interviewer: And they're a very strong union.

Interviewee: They're very strong unions. At the moment everything's going terrific. So we're trying to keep it on an even keel. (Terminal Manager, 2010)

Historically, the unions, and particularly the maritime union, have been effective, and in the current situation is seeking to adapt to the changed circumstances.

This analysis indicates that management has the capacity to undermine the influence of the previously powerful and heavily unionised front-yard workforce. By promoting depersonalised management systems they have prompted the reconfiguration of the workforce, creating a layer of staff who are in effect located in ambiguous class positions, neither unequivocally managers qua supervisors or workers. Nonetheless these new roles are operationally strategic, critical to the operation of the port terminal (Silver, 2003). However, there is no evidence that this new layer of workers have begun to leverage their work positions in terms of industrial bargaining. Whether they come to exercise this capacity is yet to be seen and will depend not only on their commitment to the exercise of associational power but also whether the scepticism of other union members can be countered. 


\section{Conclusion}

The analysis highlights the ways in which the implementation of new managerial technologies in port work at Australian container terminals has impacted the port labour process. Such developments have implications for waterfront power relations. Thus, one conclusion is that there has been a significant reconfiguration of the labour process with regard to who does what and from what location, with a concurrent shift in the balance of power on Australia's waterfront, reinforcing Finlay's, 1988 analysis about the impacts of new technologies on waterfront workers' power.

Clearly, the outcome of the re-composition of the port labour process is a more complex set of power relationships, which has profound implications for the exercise of managerial authority as well as the capacity of unions to organise and operate. For management, this re-composition suggests that they will seek continued control of work and the labour process by use of new technologies; while for workers, such developments may undermine established ways of exercising collective power; unions may have to extend their prevailing forms of collective organisation, so that they have the capacity to exercise the possibilities that may derive from the restructuring of power relations (Silver, 2003; Wright, 2000).

A second conclusion is that unions organising in the ports face major challenges in how to keep members committed to union ideals in relation to a reconfigured port workforce. The predominantly manual labour force at the waterfront has been scaled down and is increasingly replaced by a more diversified group of workers, some of whom have been trained in the uses of these technologies, others who are responsible for data collection and management, and yet others who implement and commission these systems. These employees occupy ambiguous class positions, between and beyond the clear-cut demarcation between operators and supervisors of the past (Carchedi, 1977). Moreover, sections of these new social groupings no longer enter port work in traditional ways; many no longer move from manual to non-manual labour within the organisation. The latter possesses little, if any, connection to the manual work at the yard, on the basis of which workplace solidarity was built and sustained in the past.

Although port workers historically have been well placed to defend and even advance their interests at both the national and international levels (in spite of the changing nature of their workplace) the new technology-driven transformations could be undermining these capacities (Silver, 2003: 97-103; see also ITF, 2002; Breitenfellner, 1997: 545; Turnbull, 2006). The challenge is twofold: first how to maintain a strong union presence at the docks in the face of new managerial strategies and technologies, which incrementally undermine the core of dockside solidarity - manual labour, and second, how to sustain its capacity to defend its members in the face of a shift in the configuration of organisational and political resources.

In these circumstances, the union has to step beyond the past certainties. While day-to-day measures and defences by the union may no longer apply, the corollary of the introduction of these advanced technologies is that new forms of leverage are now in place. Increasingly those who are responsible for the operation of the information communication systems are in potentially powerful positions in relation to 
work organisation and product flows. Their structural position in the labour process places them in rather strategic nodes, along with all the other workers in the process, whereby work is integrated and interlinked by these very communication and information systems. The task thus facing the unions is to tap into this new resource and leverage the position for their members and port workers in general.

\section{Bibliography}

Baird, A. J. (2000), 'Port privatization: objectives, extent, process, and the UK experience', International Journal of Maritime Economics, 2, 3, 177-194

Bayo-Moriones, A., Bello-Pintado, A. and Merino-Díaz-de-Cerio, J. (2010), 'The effects of integrated manufacturing on job characteristics', New Technology, Work and Employment, 25, 1, 63 - 79.

Barton, H and Turnbull, P. (2002), 'Labour Regulation and Competitive Performance in the Port Transport Industry: The Changing Fortunes of Three Major European Seaports', European Journal of Industrial Relations, 8, 2, 133 - 156

Barton, R. and Fairbrother, P. (2009), 'The Local is Now Global: Trade Unions Organising Globally', Industrial Relations, 64, 4, 685-793.

Beresford, A. K. C., Gardner, B. M., Pettit, S. J., Naniopoulos, A. \& Wooldridge, C. F. 2004. The UNCTAD and WORKPORT models of port development: evolution or revolution? Maritime Policy and Management, 31(2): $33-107$

Bichou, K. and R. Gray (2005), 'A critical review of conventional terminology for classifying seaports', Transportation Research Part A - Policy and Practice, 39, 1, 75-92.

Bonacich, E. and J. Wilson (2008), Getting the Goods: Ports, labor and the logistics revolution. Ithaca: NY, Cornell University Press.

Braverman, H. (1974), Labor and Monopoly Capital: Changes in the Labor Process under Monopoly Capitalism. New York, Free Press

Breitenfellner, A. (1997), 'Global Unionism: A Potential Player', International Labour Review, 136, 4, 53155.

Burawoy, M. (1979), Manufacturing Consent, Chicago: Chicago University Press.

Butcher, T. (2007), 'Supply chain knowledge work: should we restructure the workforce for improved agility?' International Journal of Agile Systems and Management, 2, 4, 376-92.

Carchedi, G. (1977) On the Economic Identification of Social Classes, London: Routledge and Kegan Paul Books.

Davis, C. (2007), 'The Politics of Ports: Privatization and the World's Ports.' International Labor and Working-Class History, 71, 154-161. 
Dabscheck, B. (2000), 'The Australian Waterfront Dispute and Theories of the State', Journal of Industrial Relations, 42, 4, 497 - 516.

Dodgson, M. (2000), The Management of Technological Innovation, Oxford: Oxford University Press.

Edwards, P. K. (1986), Conflict at Work. Oxford: Blackwell.

Finlay, W. (1988), Work on the Waterfront: Worker Power and Technological Change in a West Coast Port. Philadelphia: Temple University Press.

Griffin, G. and Svensen, S. (1998), 'Industrial Relations Implications of the Australian Waterside Dispute', Australian Bulletin of Labour, 24, 194-206.

Haezendonck, E. Pison, G. Rousseeuw, P. Struyf, A. and Verbec, A. (2000), 'The Competitive Advantage of Seaports', International Journal of Maritime Economics, 2, 2, 69-82.

Hall, P. (2009), 'Container Ports, Local Benefits and Transportation Worker Earnings', GeoJournal 74, 1, 67-83.

Haralambides, H. E., Cariou, P. and Benacchio, M. (2002), 'Costs, Benefits and Pricing of Dedicated Container Terminals', Journal of Maritime Economics, 4, 21 - 34

Held, D. (1995), Democracy and the Global Order: From the Modern State to Global Governance, Cambridge: Polity Press.

Hill, D. (2005), 'Globalisation and Labour Relations: The case of Asian ports', The 19th Association of Industrial Relations Academics of Australian and New Zealand Conference, Sydney, Australia, AIRAANZ.

Hudson, R. (2001), Producing Places, New York: Guilford Press.

ITF (2002) Globalising Solidarity, London: International Transport Workers' Federation.

Kia, M., Shayan, E. And Ghob, F. (2000), 'The important of information technology in port terminal operations', International Journal of Physical Distribution and Logistics Management 30, 3/4, 331344.

Lillie N. (2004), 'Global Collective Bargaining on Flag of Convenience Shipping', British Journal of Industrial Relations, 42, 1, 47-67.

Lukes, S. (2005), Power : A Radical View, Palgrave Macmillan.

Mangan, J., Lalwani, C. and Butcher, T. (2008), Global Logistics and Supply Chain Management, Chichester: Wiley.

McConville, C. (2000), 'The Australian Waterfront Dispute 1998', Politics \& Society 28, 3, 393-412.

Morris, R. and Donn, C. (1997), 'New technology and industrial relations in United States and Australian shipping', New Technology, Work and Employment, 12, 2, 136 - 145. 
Notteboom T and Rodrigue J. (2008), 'Containerisation, Box Logistics and Global Supply Chains: The Integration of Ports and Liner Shipping Networks', Maritime Economics \& Logistics 10, 152-174.

Silver, B. (2003), Forces of Labor: Workers' Movements and Globalization since 1870, Cambridge: Cambridge University Press.

Slack, B. (1993), 'Pawns in the Game: Ports in a Global Transportation System', Growth and Change, 24, 579- 588.

Slack, B and Frémont (2005), 'Transformation of port terminal operations: from the local to the global', Transport Reviews, 25, 1, 117 - 130

Suykens, F. and Van de Voorde, E. (1998), 'A Quarter of a Century of Port Management in Europe: objectives and tools', Maritime Policy and management, 25, 3, $251-261$.

Tarrow, S. (2005), The New Transnational Activism, Cambridge: Cambridge University Press.

Thompson, P. and Smith, C. (2009), 'Labour Power and Labour Process: Contesting the Marginality of the Sociology of Work', Sociology, 43, 5, $913-30$.

Tidd, J., Bessant, J. and Pavitt, K. (2005), Managing Innovation: Integrating Technological, Market and Organizational Change, Third Edition; Chichester, West Sussex: John Wiley and Sons Ltd

Tull, M. and Revely, J. (2001), 'The Merits of Public versus Private Ownership: A Comparative Study of Australian and New Zealand Seaports', Journal of Applied Economics and Policy, 20, 3, 75 - 99

Turnbull, P. (1988), 'The Limits to "Japanisation" - Just-In-Time, Labour Relations and the UK Automotive Industry', New Technology, Work and Employment, 3, 1, 7 - 20.

Turnbull, P. (2001), 'Re-thinking Dock Work', Labour History Review, 66, 3, 367-80.

Turnbull, P. (2006), 'The War on Europe's Waterfront: Repertoires of Power in the Port Transport Industry', British Journal of Industrial Relations, 44, 2, 305 -326.

Turnbull, P. and Wass, V. (2007), 'Defending Dock Workers - Globalization and Labor Relations in the World's Ports', Industrial Relations, 46, 3, 582612.

Walsham, G. (1993), Interpreting Information Systems in Organizations, Chichester: Wiley.

Whitley R. (1999), Divergent Capitalisms. The Social Structuring and Change of Business Systems, Oxford: Oxford University Press.

Womack, J., Jones, D. and Roos, D. (1990), The Machine That Changed the World: The Story of Lean Production, New York: Harper Perennial.

Wright, E. (2000), 'Working-class power, capitalist class interests, and class compromise', American Journal of Sociology, 105, 4, 957-1002.

Vigarié, A. 1999. From break-bulk to containers: the transformation of general cargo handling and trade, GeoJournal, 48(1): 3-7 
Von Holdt, K. and Webster, E. (2008), 'Organising on the periphery: new sources of power in the South African workplace', Employee Relations, 30, 4, 333-354. 